\title{
Pendampingan Proses Produksi Sabun Natural Mayangsari di Kelompok Bumdes Desa Pesanggrahan Kota Batu
}

\author{
Assistance for Mayangsari Natural Soap Production Process in Village-Owned Enterprises \\ Pesanggrahan Village, Batu City
}

\section{Sujono ${ }^{1^{*}}$ \\ Dian Indratmi 2 \\ Hendra Kusuma ${ }^{3}$ \\ 1Department of Animal Husbandry, Universitas Muhammadiyah Malang, Malang, East Java, Indonesia \\ 2Department of Agrotechnology, Universitas Muhammadiyah Malang, Malang, East Java, Indonesia

32Department of $\begin{array}{r}\text { Development } \\ \text { Universitas }\end{array}$
Economics,
Muhammadiyah Malang, Malang,
East Java, Indonesia

*email: sujono_umm64@yahoo.com

\section{Kata Kunci}

Sabun Natural

Susu Kambing

Minyak Zaitun

\section{Keywords:}

Natural Soap

Goat milk

Olive oil

Received: December 2019

Accepted: March 2020

Published: June 2020

\begin{abstract}
Abstrak
Sabun natural adalah sabun dengan bahan dasar menggunakan bahan herbal seperti minyak zaitun, minyak kelapa dan susu. Sabun natural MayangSari diproduksi oleh kelompok usaha bersama masyarakat Desa Pesanggrahan Kota Batu. Permasalahan produksi sabun naturaldi kelompok usaha Mayangsari adalah belum ada ijin jual dari BPOM, proses produksi sabun cair belum maksimal dimana belum mengetahui teknik mencampurkan susu dengan bahan lain sehingga mudah pisah, kekurangan peralatan sehingga produksi tidak maksimal dan manajemen pembukuan serta pemasaran yang masih manual. Tujuan program Pengabdian kepada Masyarakat skema PUBM (Program Pengabdian Usaha Bersama Masyarakat) ini adalah untuk Meningkatkan kuantitas dan kualitas sabun susu kambing etawa, memperluas jaringan pemasaran produk, dan meningkatkan kemampuan manajerial kelompok. Metode yang dilakukan dalam kegiatan Pengabdian kepada Masyarakat ini meliputi 4 tahap, yaitu praktek produksi, pelatihan, pendampingan, dan Publikasi produk. Hasil pelaksanaan program Pengabdian kepada Masyarakat ini adalah untuk meningkatkan produktivitas usaha agroindustri sabun susu kambing etawa "Olive Milk", antara lain melalui praktek produksi sabun natural dengan memanfaatkan peralatan hibah dari DPPM-UMM.
\end{abstract}

\begin{abstract}
Natural soap is a soap with basic ingredients using herbal ingredients such as olive oil, coconut oil, and milk. MayangSari natural soap is produced by a joint business group in the Pesanggrahan Village, Batu City. The problem of natural soap production in the Mayangsari business group is that there is no selling permit from BPOM, the liquid soap production process has not been maximized where it does not yet know the technique of mixing milk with other ingredients so that it is easily separated, lack of equipment so that production is not optimal and bookkeeping management and marketing are still manual. The aim of the Community Service Program (PUBM) is to improve the quantity and quality of etawa goat milk soap, expand the product marketing network, and improve the group's managerial ability. The method used in the Community Service activities includes 4 stages, namely the practice of production, training, mentoring, and product publication. The result of the implementation of the Community Service program is to increase the productivity of the agroindustry of "Olive Milk" etawa goat milk soap, among others through the practice of natural soap production by utilizing grant equipment from DPPM-UMM.
\end{abstract} Universitas Muhammadiyah Palangkaraya. This is Open Access article under the CC-BY-SA License (http://creativecommons.org/licenses/by-sa/4.0/). DOI: https://doi.org/10.33084/pengabdianmu.v5i3.1327

\section{PENDAHULUAN}

Sabun telah dikenal sejak lama yang digunakan sebagai salah satu untuk membersihkan badan ataupun mencuci. Pada umumnya sabun berbentuk padatan atau batang,lunak dan cair. Sabun merupakan campuran senyawa asam lemak (turunan asam lemak atau 
minyak) yang direaksikan dengan senyawa alkali melalui suatu proses yang dikenal sebagai saponifikasi. (Langingietal., 2012; Cavitch, 1997). Sabun natural adalah sabun dengan bahan dasar menggunakan bahan herbal seperti minyak zaitun, minyak kelapa dan susu (Retnowati et al., 2013).

Pada umumnya proses pembuatan sabun menggunakan bahan baku utama minyak atau trigliserida. Pemilihan jenis minyak mempengaruhi sifat dari sabun baik dalam jumlah busa dan pengaruhnya terhadap kulit. (Sari et al., 2018). Minyak kelapa terdiri dari asam lemak jenuh (90\%). Minyak kelapa dipilih sebagai basis karena karakteristiknya yang lebih tahan panas, tidak mudah terdegradasi (struktur kimianya tidak mengandung ikatan rangkap), dan memiliki aroma yang lebih baik dibanding dengan minyak kelapa (Tuminah, 2009; Sartika, 2008). Kandungan asam lemak jenuh berupa asam lemak laurat $\left(\mathrm{C}_{12} \mathrm{H}_{24} \mathrm{O}_{2}\right)$ dapat dijadikan sebagai bahan baku kosmetik seperti lotion, pelembab bibir, conditioner rambut, dan sabun mandi. Selain itu asam laurat mampu memberikan busa yang sangat baik sehingga terbentuk sabun padat yang bagus serta memiliki khasiat alami sebagai antimikroba (Widyasanti et al., 2017).

Minyak kelapa sawit dipilih karena mengandung asam palmitat tinggi yang membuat minyak sawit tahan oksidasi dibandingkan dengan minyak lainnya. Minyak kelapa sawit dapat menghasilkan sabun dengan karakteristik padat, bertekstur halus, melembababkan kulit dan mempercepat terjadinya trace (Zulkifli \& Estiasih, 2014). Pemilihan minyak zaitun untuk olahan sabun mandi merupakan pemilihan tepat untuk melembabkan kulit yang terbukti akan kandungan asam oleatnya terbesar pada kandungan minyak zaitun. Komponen trigliserida minyak zaitun mampu dipecahkan oleh flora normal kult menjadi gliserol yang merupakan faktor pelembab penting (humektan) pada lapisan stratum korneum dengan mencegah hidrasi pada kulit (Cooke et al., 2016).

Susu kambing memiliki kandungan kaya akan lemak protein, mineral dan vitamin yang bermanfaat untuk kesehatan kulit dengan kandungannya yang mampu melembabkan kulit.Kandungan zat asam beta hidroksil alami dalam susu kambing mampu mencerahkan kulit sehingga kulit menjadi lebih halus dan tidak bersisik. Kandungan protein dalam susu kambing berfungsi sebagai pemberi nutrisi yang berfungsi melembabkan sekaligus melapisi permukaan kulit sehingga menjadi lebih halus (Chowdhury et al., 2018).

Kualitas sabun yang beredar di Indonesia sudah diatur oleh pemerintah pada Standar Nasional Indonesia (SNI) dengan Nomor SNI 06-3532-1994. Pada SNI tersebut telah ditentukan bahwa syarat yang harus dipenuhi sabun padat antara lain kadar air tidak boleh lebih dari $15 \%$; jumlah asam lemak tergantung dari tipe sabun, adalah lebih dari 10\% untuk tipe 1, 64-70\% untuk tipe II, dan lebih dari 70\% untuk superfat ; alkali bebas tidak boleh lebih dari 0,1\%; kadar asam lemak bebas atau asam lemak netral adalah kurang dari 2,5\% untuk tipe I dan II, dan 2.5-7.5\% untuk superfat, terakhir sabun mandi padat harus bebas minyak mineral.

Sabun natural MayangSari diproduksi oleh kelompok usaha bersama masyarakat Desa Pesanggrahan Kota Batu. Kelompok ini didirikan melalui pelatihan keterampilan usaha oleh Badan Usaha Milik Desa atau Bumdes Desa Pesanggrahan Kota Batu sekitar pertengahan Agustus 2018 tepatnya 19 Agustus 2018, dengan jumlah anggota kelompok anggota 11 orang. Kelompok usaha MayangSari merupakan kelompok usaha yang berfokus pembuatan sabun natural berbahan susu kambing dan minyak nabati. Kelompok usaha MayangSari mempunyai tempat produksi di BLK Bumdes MayangSari Jl Balai Desa, Pesanggrahan Kota Batu. 
Permasalahan produksi sabun natural di kelompok usaha Mayangsari adalah belum ada ijin jual dari BPOM, proses produksi sabun cair belum maksimal dimana belum mengetahui teknik mencampurkan susu dengan bahan lain sehingga mudah pisah, kekurangan peralatan sehingga produksi tidak maksimal dan manajemen pembukuan serta pemasaran yang masih manual. Untuk itu perlu diberikan program pengabdian Usaha Bersama Masyarakat(PPUBM) ini guna memperolehijin dari BPOM dan produksi sabun bisa maksimal dan meningkatkan produksi dan perbaikan manajemen usaha.

\section{METODOLOGI}

Metode yang dilakukan dalam kegiatan Pengabdian kepada Masyarakat ini meliputi 4 tahap, yaitu Praktek produksi, Pelatihan, Pendampingan, dan Publikasi produk. Berikut adalah uraian dari masing-masing tahap kegiatan:

1. Tahap praktek produksi merupakan kegiatan praktek bersama kelompok dalam memproduksi sabun susu natural dengan memanfaatkan Teknologi Tepat Guna berupa satu set peralatan produksi sabun susu dan cetakan sabun berbahan silicon.

2. Tahap pelatihan adalah proses yang didesain untuk meningkatkan pengetahuan dan keterampilan kelompok dan anggotanya, yaitu terdiri dari pelatihan membuat formula sabu berbasis komputasi dengan menerapkan program "soapcalv", pelatihan desain kemasan, pelatihan pemasaran berbasis Teknologi Informasi dan pelatihan manajemen pembukuan sederhana.

3. Tahap pendampingan adalah suatu proses pemberian fasilitasi kepada kelompok untuk mendorong kemandirian secara berkelanjutan, merupakan kelanjutan dari tahap pelatihan.
4. Publikasi produk merupakan upaya untuk memperkenalkan dan mempromosikan produk yang dihasilkan ke masyarakat melalui pameran/ gelar produk, media online dan leaflet/ brosur.

\section{HASIL DAN PEMBAHASAN}

Perbaikan Proses Produksi Sabun Susu Padat dan Cair Sampel sabun mitra merupakan sabun susu padat dan cair dengan menggunakan bahan Susu kambing, $\mathrm{NaOH}$, Minyak kelapa,minyak kelapa yang diolah menjadi VCO, minyak zaitun dan 5 macam ekstrak pewangi. Sampel sabun telah mengalami pemeraman (curing) hampir 2 bulan. Berdasar hasil uji sampel produk sabun susu padat mitra, perlu dilakukan upgrading dengan formulasi yang tepat penggunaan minyak nabati sebagai bahan baku kedua. Sabun produk mitra lebih merupakan sabun minyak zaitun dan VCO yang ditambah susu sebagai pengisi. Selain itu edukasi penggunaan material proses juga diperlukan terutama mengenai sifat eksotermis pelarutan basa $\mathrm{NaOH}$. Hasil uji menunjukkan secara visual sabun susu padat yang diperoleh memiliki tekstur yang lembut/halus di kulit tetapi terlalu lunak, mudah hancur, menghasilkan sedikit busa, dan kadar alkali bebas yang tinggi dan tidak mudah leleh.

Perbaikan sabun cair dengan menambahkan bahan pengemulsi agar campuran air susu kambing dengan lemak bisa bercampur dan stabil. Sebelum kegiatan sabun cair setalah 2 minggu mulai memisah antara susu kambing dengan minyak, sehingga ada perbaikan hasil sabun natural cair menjadi stabil tidak memisah walau satu bulan. Sabun cair yang diproduksi dalam dua kemasan yaitu $100 \mathrm{ml}$ dan $250 \mathrm{ml}$.

Hasil pengujian stabilitas busa sabun padat dan cair dilakukan untuk mengetahui banyaknya busa yang dihasilkan pada pemakaian sabun dan hasilnya lebih stabil dibandingkan sebelum dilakukan pendampingan. 
Busa adalah struktur yang relatif stabil yang terdiri dari kantong-kantong udara yang terbungkus lapisan tipis, yang merupakan dispersi gas dalam cairan yang distabilkan oleh suatu zat pembusa yang bersifat aktif permukaan (sabun). Kecepatan pembentukan dan stabilitas busa yang dihasilkan merupakan dua hal penting untuk produk pembersih tubuh. Busa yang banyak dan stabil lebih disukai daripada busa yang sedikit dan tidak stabil (Martin et al., 1993). Kestabilan busa dihitung sebagai perbandingan dalam persen antara tinggi awal terhadap tinggi akhir busa dalam tabung reaksi setelah satu jam pengocokan dengan vortex (Goon et al., 1999).

Uji penerimaan produk oleh calon konsumen merupakan salah satu uji yang menyangkut penilaian seseorang terhadap kesukaan atau ketidaksukaan suatu produk. Uji kesukaan dilakukan untuk mengetahui tingkat penerimaan konsumen terhadap sabun susu yang dihasilkan. Kriteria uji penerimaan calon konsumen yang dilakukan meliputi aroma, daya busa, dan tekstur dalam penggunaan. Total responden pada uji ini sebanyak 25 orang pengguna. Hasil uji menunjukkan sabun susu padat hasil formulasi mempunyai nilai lebih dalam hal daya busa dan tekstur di kulit dibanding sabun susu komersial. Daya pembusaan produk sabun susu padat dapat ditingkatkan dengan memperbesar kandungan minyak kelapa. Tetapi aroma sabun susu padat hasil formulasi sedikit tidak disukai dibanding sabun susu komersial.

Pilihan menggunakan minyak nabati yang diusulkan adalah minyak zaitun, minyak kelapa VCO dan susu kambing karena menghasilkan kualitas sabun padat dan cair lebih bagus dibanding minyak sawit dan susu sapi. Kelemahan hanya pada harga jual sabun yang lebih mahal disbanding sabun biasa harga minyak zaitun relatif mahal, akan tetapi dengan mengangkat keekslusif-an sabun susu sebagai sabun perawatan kulit, penggunaan minyak zaitun dan susu kambing menjadi nilai tambah.

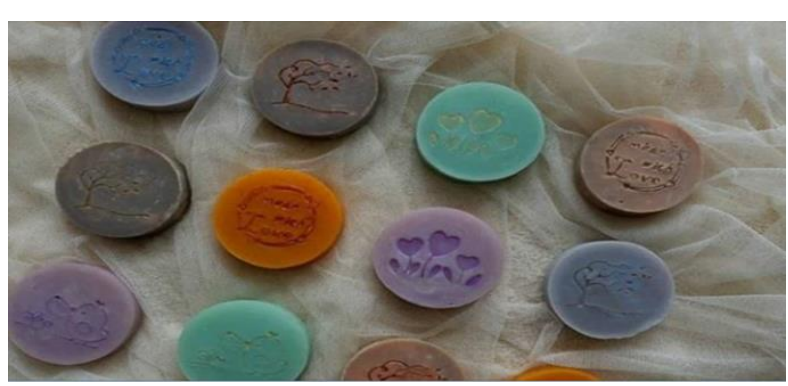

Gambar 1. Sabun Natural “MayangSari Padat dengan 5 Aroma

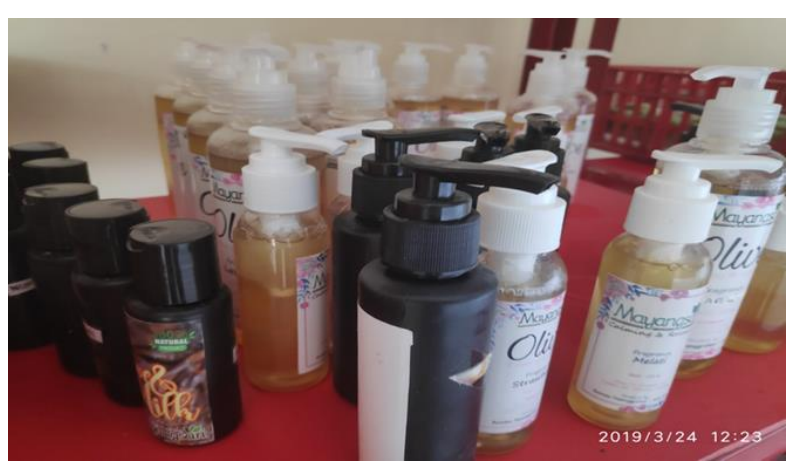

Gambar 2. Sabun Natural “MayangSari Cair dengan 5 Aroma

Pelaksanaan Program dan Dampaknya

Pelaksanaan program dilakukan dengan pelatihan/workshop di tempat Rumah Produksi Sabun Naturat di dekat Balai Desa Pesanggrahan Kota Batu. Selain perbaikan resep dan formulasi pembuatan sabun secara komputasi dengan menggunakan software "soapcalv" juga pelatihan pembuatan pembukuan sederhana dan pemasaran secara on-line.

\section{KESIMPULAN}

Program pengabdian masyarakat yang dilakukan oleh Tim PPUBM ini merupakan aplikasi keilmuan untuk teknologi sederhana yang tepat guna bagi masyarakat pedesaan. Hasil pengabdian masyarakat terbukti bermanfaat untuk memperbaiki proses pembuatan sabun natural padat dan cair yang lebih berkualitas memenuhi standar SNI 06-3532-1994. 


\section{REFERENSI}

Cavith, S.M. 1997. The Soapmaker's Companion: A Comprehensive Guide with Recipes, Techniques Know-How. Massachusetts, US: Storey Publishing, LLC.

Chowdhury, M.R., Khan, M.M.H., Mahfuz, S.U., Baset, M.A. 2018. Effects of Dietary Supplementation of Spices on Forage Degradability, Ruminal Fermentation, in Vivo Digestibility, Growth Performance and Nitrogen Balance in Black Bengal Goat. Journal of Animal Physiology and Animal Nutrition. 102(2):591-598. https://doi.org/10.1111/jpn.12800

Cooke, A., Cork, M.J., Victor, S., Campbell, M., Danby, S., Chittock, J., Lavender, T. 2016. Olive Oil, Sunflower Oil or No Oil for Baby Dry Skin or Massage: A Pilot, Assessor-blinded, Randomized Controlled Trial (The Oil in Baby SkincaRE [OBSeRvE] Study). Acta DermatoVenereologica. 96(3):323-330. https://doi.org/10.2340/00015555-2279

Goon, P., Bhirud, R.G., Kumar, V.V. 1999. Detergency and foam studies on linear alkylbenzene sulfonate and secondary alkyl sulfonate. Journal of Surfactants and Detergents. 2:489-493. https://doi.org/10.1007/s11743-999-0097-0

Langingi, R., Momuat, L.I., Kumaunang, M.G. 2012. Pembuatan Sabun Mandi Padat Dari VCO Yang Mengandung Karotenoid Wortel. Jurnal Ilmiah Sains. 1(1):20-23. https://doi.org/10.35799/jm.1.1.2012.426

Martin, A., Swarbrick, J., Cammarata, A. 1993. Farmasi Fisik: Dasar-Dasar Kimia Fisik Dalam Ilmu Farmasetik Jilid 2 (Terjemahan). Jakarta: Universitas Indonesia Press.

Retnowati, D.S., Kumoro, A.C., Ratnawati, Budiyati, C.S. 2013. Pembuatan dan Karakterisasi Sabun Susu dengan Proses Dingin. Jurnal Rekayasa Proses. 7(2):45-50. https://doi.org/10.22146/jrekpros.4951

Sari, N.M.P., Wrasiati, L.P., Suhendra, L. 2018. Pengaruh Perbandingan Minyak Kelapa (Cocos nucifera) dengan Lemak Kakao (Theobroma cacao L.) dan Suhu Pemanasan Terhadap Karakteristik Sabun. Jurnal Rekayasa dan Manajemen Agroindustri. 6(4):297-306.
Sartika, R.S.D. 2008. Pengaruh Asam Lemak Jenuh, Tidak Jenuh dan Asam Lemak Trans terhadap Kesehatan. Kesmas: National Public Health Journal.

2(4):154-160. http://dx.doi.org/10.21109/kesmas.v2i4.258

Tuminah, S. 2009. Efek Asam Lemak Jenuh Dan Asam Lemak Tak Jenuh "Trans" Terhadap Kesehatan. Media Penelitian dan Pengembangan Kesehatan. 19(Suppl.II):13-20.

Widyasanti, A., Junita, S., Nurjanah, S. 2017. Pengaruh Konsentrasi Minyak Kelapa Murni (Virgin Coconut Oil) dan Minyak Jarak (Castor Oil) terhadap Sifat Fisikokimia dan Organoleptik Sabun Mandi Cair. Jurnal Teknologi dan Industri Pertanian Indonesia. 9(1):10-16. https://doi.org/10.17969/jtipi.v9i1.6383

Zulkifli, M., Estiasih, T. 2014. Sabun Dari Distilat Asam Lemak Minyak Sawit: Kajian Pustaka. Jurnal Pangan dan Agroindustri. 2(4):170-177. 